\title{
RECONSTRUCTIONS OF ARCHAEOPTERIS, AND FURTHER CONSIDERATION OF ITS PHYLOGENETIC POSITION ${ }^{1}$
}

\author{
Charles B. Beck ${ }^{2}$ \\ Department of Botany, University of Michigan, Ann Arbor, Michigan
}

\section{A B S T R A C T}

Beck, C. B. (U. Michigan, Ann Arbor.) Reconstructions of Archaeopteris, and further consideration of its phylogenetic position. Amer. Jour. Bot. 49(4):373-382. Illus. 1962--Two reconstructions, one of a branch bearing the basal part of 3 leaves and the other of the habit, are presented with the evidence upon which they are based. An analysis is made of some features which characterize the ferns. These, and characters of Archaeopteris, are considered in the light of present knowledge of evolutionary trends, and the conclusion is reached that Archaeopteris was neither a primitive fern nor a fern ancestor. Additional evidence is discussed which supports the view that the plant was a progymnosperm.

The conRelation of Archaeopteris and Callixylon (Beck, 1960a,b) makes possible the preparation of relatively accurate reconstructions of the Upper Devonian and Lower Mississippian plant represented by these organ genera. Two reconstructions and presentation of the evidence on which they are based form the first objective of this paper. The second is to discuss further the phylogenetic position of this plant, including additional evidence which supports the view that Archaeopteris is a progymnosperm (Beck, 1960b).

Reconstructions-No single species of $\mathrm{Ar}$ chaeopteris is known in sufficient detail to provide an accurate picture of a large part of the plant, but such a picture can be obtained by pooling information from several species. Figure 1 shows a branch segment bearing the basal parts of 3 leaves, one of which is fertile. This reconstruction, including the size and spatial relationships of various structures portrayed, is based largely on the illustrations of Archaeopteris fimbriata in Nathorst (1902) and on the specimen which I have recently described and identified as Archaeopteris cf. macilenta (Beck, 1960b). Archaeopteris fimbriata Nathorst (1902) is considered a synonym of A. macilenta Lesquereux (1884) by Kräusel and Weyland (1941).

The spiral arrangement of the leaves was determined by Arnold (1930) on the basis of the sequence of leaf-trace departure in Callixylon zalesskyi. This is confirmed by the specimen of $A$. of. macilenta in which several leaf fragments are borne spirally on a branch identified as $C$. zalesskyi. Arnold reported the origin of 4 leaf traces within a distance of $1.5 \mathrm{~cm}$ in his specimen which suggests that the leaves were closer together than

\footnotetext{
${ }^{1}$ Received for publication August 31, 1961.

Supported by National Science Foundation Grant 13223.

${ }^{2} \mathrm{I}$ am indebted to Professors Arthur J. Eames and Irving $W$. Bailey for their critical reading of the manuscript. For assistance in the preparation of Fig. 1, I extend thanks to G. Kadambari Kumari. The skill of Elizabeth Anthony is apparent in Fig. 2. Her patience and cooperation are acknowledged with appreciation.
}

those illustrated in Fig. 1. This apparent discrepancy may be explained by assuming that the leaf traces diverged in their passage from the stele to the leaf bases. Or, I may have incorrectly identified the wood of $A$. cf. macilenta as Callixylon zalesskyi, since the identification was based on only a few slides of pyritized wood. The distance between leaves may be related to leaf size; the larger the leaves, the more widely spaced. And considerable variation in leaf size among the several species of Archaeopteris is to be expected.

In this regard, a rather intriguing suggestion has been made by W. S. Lacey (personal communication, 1961) who wonders if Archacopteris might not have borne both simple and compound leaves. There is no evidence of simple leaves on the specimen of $A$. ef. macilenta, unless the stipules fall into this category. The stipules do appear to be attached to the stem, immediately subtending the leaves, rather than to the petiole (Beck, 1960b, pl. 25, Fig. 2, 3). Lacey's suggestion is especially interesting in view of the proposal of the occurrence of both microphylls and megaphylls in some members of the Zygopteridaceae by Eggert (1961).

The presence of a stipule at the base of the Archaeopteris leaf has been illustrated by Nathorst (1902) in both $A$. fimbriata and $A$. roemeriana (halliana), Johnson (1911) in A. hibernica, Beck (1960b) in A. cf. macilenta, and possibly others. The forked nature of this structure is well illustrated by Nathorst.

The basal enlargement of the rachis (petiole) is illustrated in Nathorst (1902) and Johnson (1911). The adaxial concavity near the base and the convex abaxial surface of the rachis are entirely hypothetical, since only compressions have been uncovered in the fossil record. The rachial pinnules near the base of the leaves have been often observed and may be documented by reference to Lesquereux (1884), Nathorst (1902) and Johnson (1911). Opposite to sub-opposite, rachial pinnules between both fertile and vegetative pimnae are illustrated in the 2 latter papers and by Arnold (1939) in a vegetative specimen. I have recently 


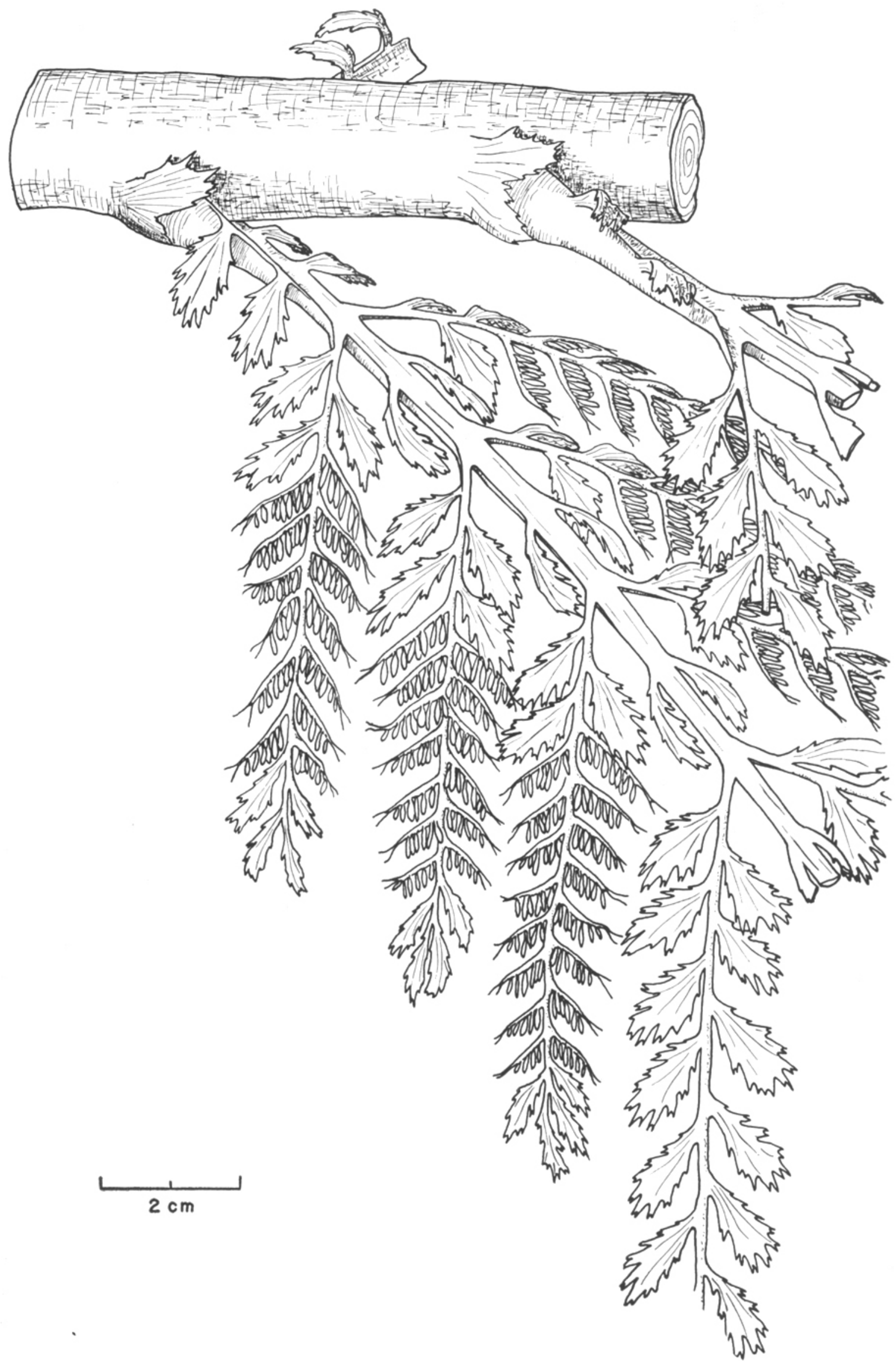


c sllected beautifully preserved specimens which also show this feature.

Although, rarely, the pinnae may be alternate (Arnold, 1939), the most common arrangement in the genus is opposite to sub-opposite. Occasionally, the basal pinna may occur opposite a rachial pinnule instead of opposite a pinna (Lesquereux, 1884; Arnold, 1939).

The vegetative pinnules are sub-opposite to alternate, sessile to short-stalked, and obovate, spatulate, or rarely cuneiform, with the margin varying from nearly entire in $A$. obtusa and A. halliana (see Arnold, 1939) to deeply and finely dissected in $A$. macilenta (fimbriata) (Nathorst, 1902; Arnold, 1936; Beck, 1960b) and A. fissilis (Schmalhausen, 1894). Venation is dichotomous. The vegetative pinnules in Fig. 1 are based on those of the specimen of $A$. macilenta illustrated by Arnold (1936, Fig. 1). Within the genus, the pinnules vary greatly in size-from 1 $\mathrm{cm}$ or less to $2 \mathrm{~cm}$ or more - and may overlap or be spaced, as in $A$. macilenta. Figures in numerous papers show that pinnules of both fertile and vegetative pinnae gradually decrease in size distally.

The fertile pinnae, which occur basally on some fronds, bear proximally several alternate vegetative pinnules which are followed by a series of fertile pinnules bearing 1 or 2 rows of sporangia. Several vegetative pinnules terminate the pinna. Agreement has not been reached on whether there is only 1 or whether there are 2 rows of sporangia on the fertile pinnules. Johnson (1911) thought there was a single row, whereas Kräusel and Weyland (1941) suggested that there were 2 rows. Arnold's illustrations of fertile pinnules of $A$. latifolia $(1939$, pl. 9, Fig. 3,4) suggest only 1 row, but he does not give an opinion on this question. The occurrence of proximal vegetative pinnules on the fertile pinnae has been observed frequently (Lesquereux, 1879, pl. 50, Fig. 3; Schimper, 1869, Atlas pl. 36; Nathorst, 1902; Johnson, 1911, and others). The existence of terminal vegetative pinnules has been less frequently reported due, undoubtedly in some specimens, to poor preservation of the tips of the pinnae. Good illustrations appear in Schimper (1869), Nathorst (1902) and Johnson (1911). It is, of course, quite possible that in some specimens, or in some species, the pinnae were terminated by fertile pinnules, or that the pinnae were wholly fertile, lacking vegetative pinnules entirely. The homology between the fertile and vegetative pinnules is shown in those cases where a pinnule is partly fertile and partly vegetative (see Schmalhausen, 1894, pl. II, Fig. 19-21; Johnson, 1911). The fertile pinnules often extend out into a sterile tip, sometimes forked (Nathorst, 1902; Johnson, 1911; Arnold, 1939, pl. 9, Fig. 3, 4; Kräusel and Weyland, 1941).
The reconstruction in Fig. 1 represents, specifically, Archaeopteris macilenta Lesquereux. In general features, it and the following habit reconstruction portray the genus Archaeopteris. The reconstruction (Fig. 2) is based in large part on the discussion of the habit of Callixylon by Arnold (1931) and the specimen of Archaeopteris ef. macilenta which consists of Archaeopteris leaf fragments attached to a branch of Callixylon (Beck, 1960b). Figure 2 depicts a tree 60 or more ft tall, the trunk tapering from a base of about $5 \mathrm{ft}$ in diameter. Perhaps the largest known specimen of Callixylon is a stump about $5 \mathrm{ft}$ in diameter from the Woodford chert of Oklahoma, now reconstructed on the campus of East Central State College in Ada, Oklahoma (Wilson, 1958). Logs 2-3 ft in diameter are common in the New Albany shale in Indiana and Kentucky, and a 28 -ft segment of a log has been discovered in the Caballos chert of Southwest Texas (Bennett, 1959). On the basis of the taper of specimens in the Museum of Paleontology of the University of Michigan and the U. S. National Museune, Arnold estimated the tree represented by the Oklahoma stump to have had "a minimum height of sixty feet." The absence of exposed lateral branches on Callixylon logs has suggested to Arnold (1931) that the branches did not attain a great diameter, probably indicating their caducous character. This indicates a tree of excurrent habit with an apical crown of branches much as in the living pines. The main lateral branches would probably be nearly horizontal or inclined upward only slightly as illustrated in Fig. 2, and the more distal parts might have been bent downward by the weight of the large, compound leaves which varied in length from $2 \mathrm{ft}$ or less to as much as $5 \mathrm{ft}$ (see Johnson, 1911). Smaller branches diverged from the main laterals at angles as great as $45^{\circ}$ (Arnold, 1931).

The form of the crown of leafy branches is, of course, primarily speculative, based on that of living conifers which branch in a manner similar to that proposed for Archaeopteris. A somewhat similar branching pattern is illustrated in the reconstruction of Callixylon in Life Magazine, September 7, 1953, page 63, which was prepared in consultation with Professor C. A. Arnold.

Although we now have a fairly good knowledge of Archaeopteris as an entire plant, there is much yet to learn. Was the genus heterosporous or were some species homosporous? Arnold (1939) has presented evidence for heterospory in A. latifolia, and Kräusel and Weyland (1941) suggest the possibility of heterospory in $A$. halliana and $A$. hibernica, based on variation in sporangium size. Spores of only one size, however, were found in $A$. cf. macilenta (Beck, 1960b). Concerning this problem, Professor T. M. Harris (personal communication, 1961) writes: "May I suggest the

Fig. 1. Archaeopteris. Reconstruction of a branch bearing the basal parts of 3 leaves. Based largely on A. macilenta. About natural size. 


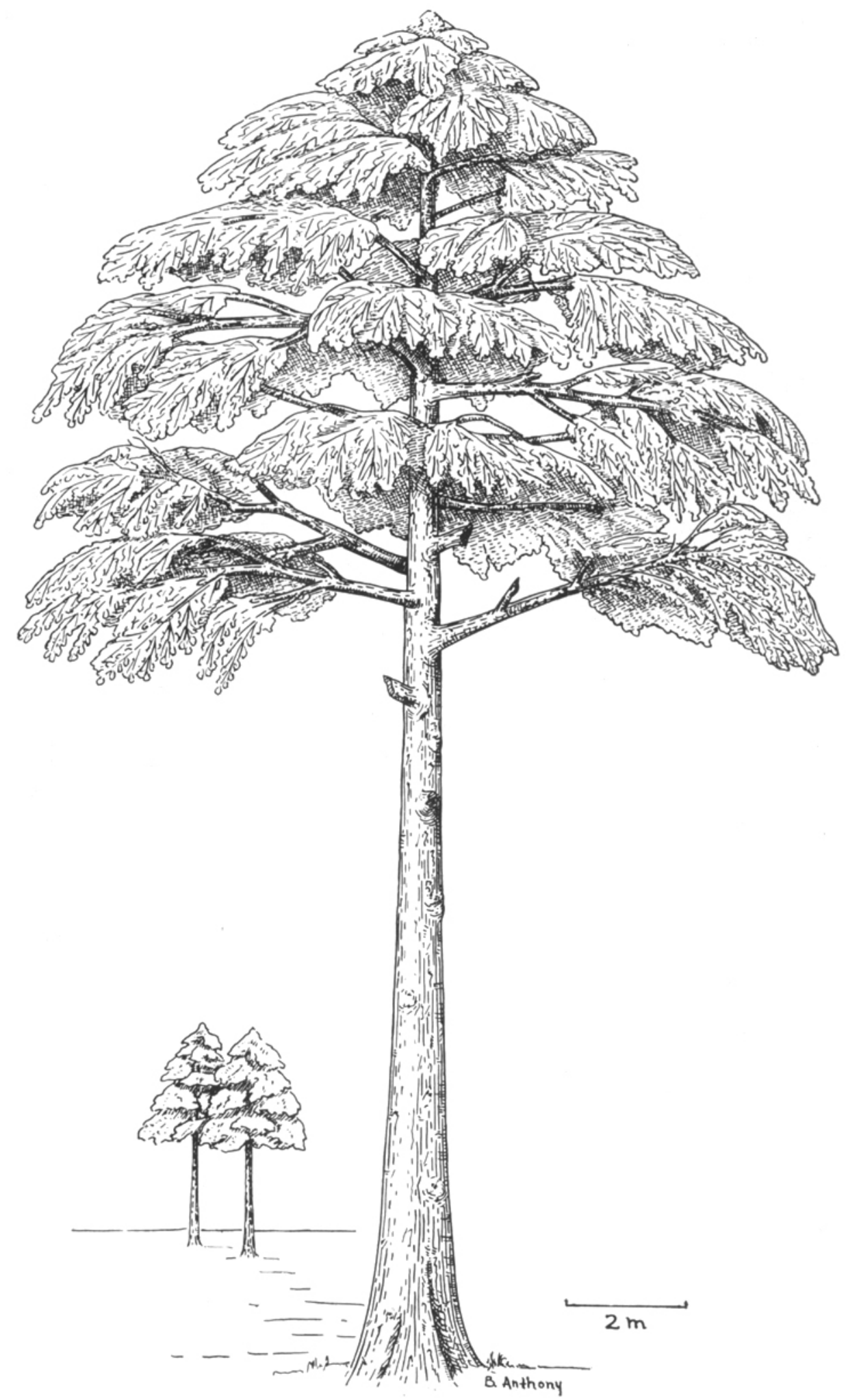

Fig. 2. Archaeopteris. Habit reconstruction. 
likelihood that some [species] are monoecious and others dioecious, or at least tend to have megaand microsporangia on different leaves or branches." Such a condition could account for the isolation of spores of but one size from $A$. cf. macilenta.

Did any species produce seeds? Arnold (1935) discovered seed-like compressions in association with Archaeopteris foliage, but none has ever been found attached.

We cannot yet answer these questions with any certainty. We know nothing about the leaf trace immediately prior to its entry into the leaf base, or about the internal structure of the rachis, and there is still much to learn about variation within species, valid criteria for distinguishing species, etc. Nevertheless, Archaeopteris is more completely known than any other Upper Devonian plant-better, possibly, than any other Paleozoic plant. Consequently, one can determine its general phylogenetic position with a good deal of certainty, although its precise position in relation to its immediate ancestors and descendants presents a more difficult problem.

The Phylogenetic POSITION OF ARCHAEOPTERIS-Of several suggestions regarding the phylogenetic position of this plant, 2 have seemed to merit the most serious consideration. These are that it is: (1) a primitive fern, representing a major group from which Coenopteridales, Ophioglossales, Marattiales and Filicales, or some of these, evolved; and, (2) a progymnosperm, representing a major group of pteridophytes from which one or more groups of gymnosperms has evolved. I have elsewhere expressed the view that the second of these alternatives is the correct one. Because, however, some other morphologists support the former, I feel that it is important to present, in much greater detail than previously (Beck, 1960b), my reasons for rejecting it.

To consider Archaeopteris a fern, or a member of a group of fern ancestors, one must be able to show that its characteristics are those generally recognized as attributable to ferns, or are of a type from which those of ferns could logically have been derived; or there must be evidence of the existence of forms of character intermediate betwcen this group and plants generally accepted as ferns. It is generally accepted that ferns are megaphyllous pteridophytes bearing foliar sporangia, and that most of them possess mesarch primary xylem. These characters, also features of Archaeopteris, do not, however, adequately define a fern. There are other important and distinctive features which must be considered. It is recognized, of course, that within the Filicineae the several orders, Coenopteridales, Ophioglossales, Marattiales and Filicales, each has its own distinctive characters. Eames (1936) suggests that the "...'ferns' ... are, ... if considered a unit group, polyphyletic." That they are at the same time a group of genetically related members sharing many common characters has been supported recently by the recognition of a fern division, called Pterophyta by Bold (1956) and Filicophyta by Cronquist (1960), which includes the orders listed above.

I should like to note and discuss some important common characters in addition to those listed above which seem to me to characterize generally the groups comprising the Filicineae, and then to consider their applicability to Archaeopteris.

(1) Primary growth only and the consequent lack of cambial activity are characteristic of the Filicineae-This feature is not only restricted to the low, "shrubby," forms, but also characterizes the large, arborescent genera of the Dicksoniaceae, and the Marattiales, the latter considered to be among the most primitive groups of ferns, including the widespread Carboniferous and Permian genus, Psaronius.

Opinion of the number of extant genera in the Filicineae varies from about 145 (Bower, 1926, 1928 ) to 308 (Copeland, 1947); and Holttum (1949) recognizes approximately 180 genera. Including the structurally preserved fossil genera, it seems conservative to conclude that there are at least 225 widely recognized genera of ferns. Of these, only 4 or 5 seem to be characterized by the production of secondary tissues. Although Sahni (1932) and others have referred to secondary wood in Zygopteris, Baxter (1952) presents an argument for the primary nature of this tissue. Kräusel and Weyland (1941) describe and illustrate secondary xylem in the stem of Rhacophyton incertum, and Leclercq (1951) refers to a similar, though less extensive tissue in $R$. zygopteroides. Among the living genera, aside from Botrychium, only Angiopteris has been reported to produce secondary xylem (Farmer and Hill, 1902), and this locally, in very small amounts. This report needs further substantiation before it can be accepted without reservation. Scott (1920) reports secondary xylem in Ankyropteris corrugata and Metaclepsydropsis duplex, but recent studies of American species of Ankyropteris (Baxter, 1951; Eggert, $1959 \mathrm{~b})$ include no mention of secondary xylem, and it is probable that this tissue was not a constant feature in these genera. The Cladoxylales, sometimes grouped with the ferns (Arnold, 1947), sometimes with the pteridosperms (Scott, 1923), and admittedly of uncertain systematic position, produced secondary xylem. This group is of interest because of its polystelic vascular system. Leclereq and Banks (1959) have shown that Pseudosporochnus, previously called a psilophyte, had cladoxylalean anatomy. The report of secondary xylem in Osmundites kidstoni by Stopes (1921) was shown by Posthumus (1924) to be in error.

One may conclude, therefore, that clear-cut examples of secondary growth among the ferns are rare and that primary growth only is generally characteristic of the Filicineae. 
(2) Scalariform pits characterize the xylem of ferns-Not only the primary xylem of most genera, but also the secondary xylem of all but one (excluding the Cladoxylales) of those which produce this tissue contain tracheids with scalariform pits. Distinct circular bordered pits are a known constant feature of only 3 genera of Filicineae, Ophioglossum, Botrychium, and Helminthostachys of the Ophioglossales. Circular bordered pits occur in the late protoxylem and metaxylem of these genera (Bierhorst, 1960) and also in the secondary xylem of Botrychium. Localized occurrences of circular bordered pits have been reported in the metaxylem of several coenopterid ferns and are discussed below. Bierhorst (1960) reports the rare presence of circular bordered pits in some predominantly reticulate elements of Marattia alata.

(3) The primary xylem and phloem of the leaf traces and stelar bundles is always concentrically arranged-I know of no exception to this character among plants usually included within the Filicineae, and the phloem always surrounds the xylem. In contrast, the traces and vascular bundles in the gymnosperms are, most commonly, collateral, although in a few genera such as Calamopitys, Iyzinopteris and Callistophyton (Delevoryas and Morgan, 1954b) the petiolar bundles may be concentric.

(4) The Filicineae are characterized by adventitious roots which often arise at the base of leaves-In respect to this character a quotation from Bower (1923, p. 337) is appropriate: "The shoot is fixed in the soil by numerous roots, of which all the later are clearly adventitious. The nature and origin of the first root may be open to question. That origin is not constant in time or place for all Ferns. The root may actually be absent in Salvinia. Its emergence where there is a suspensor present is lateral. These facts indicate that it is accessory to the shoot, as are all those which follow accessory to the shoots which bear them." Little is known about the root-stem relationship of some fossil ferns, but the occurrence of adventitious roots in the Coenopteridales has been often demonstrated (e.g., Scott, 1920; Delevoryas and Morgan, 1952, 1954a).

In the preceding paragraphs I have presented a group of characters that I believe typify and unify the group Filicineae. In a sense, I have presented my own "type concept" of a fern. The ferns have, of course, never been static. As a group (or as several groups) they have diverged from one or more evolutionary lines; the primitive ferns have given rise to the more advanced groups; and, possibly, other major groups of vascular plants have been derived from some group or groups of ferns. The pro-ferns undoubtedly were different in many ways from the primitive filicineans, but, in my opinion, they could not have possessed the combination of characters of Archaeopteris.
If the paleozoic ferns had been derived from Archaeopteris, there should be evidence in the fossil record of a trend of reduction from the woody to the herbaceous habit. Such evidence is unknown at present. The genera reported to produce secondary wood are members of the more primitive eusporangiate groups of ferns, Coenopteridales, Ophioglossales and Marattiales, but the secondary activity in these groups, scattered among a few genera, in no way suggests a major line of evolutionary specialization toward the acquisition of the woody habit, or toward a reduction from a woody habit. Eames (1936), in comparing the Ophioglossales, Marattiales and Filicales, noted that: "So distributed are the differences that it is apparent that the three groups are not closely related, and that no one of them represents an ancestral stock from which the others may have been derived." Although the Coenopteridales have long been considered the ancestral fern stock, the view that they may be, rather, an independent branch of the main line of fern evolution is gaining adherents. At present, the occurrence of secondary xylem in several diverse groups of ferns and fern-like plants seems, therefore, to be of importance only in indicating the potential within the Filicineae for secondary growth, a potential which was not as fully exploited by the ferns as by several other major groups.

To derive the ferns from Archaeopleris or its close relatives, one must assume the evolution of the scalariform bordered pit from the circular bordered pit, since the Paleozoic ferns, which produced secondary xylem, possessed scalariformly pitted secondary tracheids. Although the circular bordered pit may very well be an equally primitive type, there is little evidence that the scalariform pit has evolved from the circular pit in any group of vascular plants. Bailey $(1925,1953)$ and Frost (1931) present strong support for the view that the circular bordered pit has been derived from the scalariform pit in the gymnosperms and angiosperms. Their conclusions regarding pit evolution in angiosperms have been supported by the observations of many other workers during the last several decades. Bierhorst (1960) has suggested, however, that the circular bordered pits in the primary xylem of conifers and some related groups as well as in Equisetum and the Ophioglossales might not have evolved by a phylogenetic break up of scalariform bordered pits in the metaxylem, but probably evolved as circular bordered pits in the protoxylem. His view is based on the presence of circular bordered pits in the late protoxylem of these groups, and the absence of transitional types between scalariform and circular bordered pits in the metaxylem of the genera studied.

In the coenopterid ferns, Anachoropteris clavata (Delevoryas and Morgan, 1954a), Apotropteris minuta (Morgan and Delevoryas, 1954), Tubi- 
caulis stewartii, and T. scandens (Eggert, 1959a), pitting of the protoxylem is uniseriate-scalariform, whereas the metaxylem is typically multiseriatescalariform in the first 3 and multiseriate-reticulate in the last species, and in $T$. sutcliffi, the larger metaxylem elements are characterized by bordered pits (Delevoryas and Morgan, 1952). Such developmental sequences suggest a possible derivation of the circular bordered pit from the scalariform in these groups. In Anachoropteris clavata and Tubicaulis stewartii, transitional and circular bordered pits characterize the petiolar xylem, whereas tracheids of the stem possess the typical scalariform pits. It should also be noted that pits approaching a circular bordered type occur in the Osmundaceae and in some other extant leptosporangiate ferns. Some of the lastformed metaxylem elements of Osmunda cinnamomea stem bear some very short, opposite scalariform pits, pairs of which approximate the relative position of single, vertically adjacent, scalariform pits (Bierhorst 1960, Fig. 137). Earlier differentiated metaxylem elements of this species are characterized by uniseriate scalariform bordered pits. Bierhorst (Fig. 155) also illustrates oval or lens-shaped pits from the rachis of Onoclea sensibilis. Similar pits have also been observed in several other higher Filicales by Richard A. White (unpublished). It may also be significant that in the Paleozoic ferns such as Zygopteris and Rhacophyton, which produced secondary xylem, the pits were scalariform, and that the single genus within the Filicineae that typically produces secondary tracheids bearing bordered pits, Botrychium, is a living group with no fossil record.

This evidence suggests that in the ferns (with the possible exception of the Ophioglossales), as in the angiosperms, the circular bordered pit has been derived from the scalariform.

If Archaeopteris represents an ancestral fern group, the typical concentric arrangement of primary xylem and phloem in the leaf traces and stelar bundles of the typical fern must have been derived from the collateral arrangement. The collateral arrangement is characteristic of the gymnosperms and angiosperms and is generally considered the advanced condition. Certain paleozoic genera, primitive gymnosperms or progymnosperms such as Calamopitys, Lyginopteris and Callistophyton, are intermediate in character, possessing collateral stelar bundles and concentric leaf traces, and suggest a derivation of the collateral condition in the gymnosperms from the concentric condition. Although we do not know in detail the appearance of the stem of Archaeopteris in the solely primary condition, the vascular bundles of the stele were probably collateral, judging from the absence of internal phloem. This seems to eliminate Archaeopteris as an ancestral form from which the typical concentric arrangement of the ferns might have evolved.

Archaeopteris roots have not been discovered in attachment to stems (Callixylon), but because of the nearly identical anatomy of the secondary wood of root and stem there is no question as to the identity of the roots of this plant (Beck, 1953). This similarity in structure, the production of secondary tissues, and the habit of the plant make it most unlikely that the roots were adventitious, rather, they were probably an important part of the axial system. I am not aware of any evidence to suggest that Archaeopteris, through reduction, has become modified into an herbaceous plant with adventitious roots.

Because Archaeopteris does not possess some of the important distinguishing characters of the ferns, because there are no recognizable intermediates, and because, considering our knowledge of evolutionary trends of cell types and tissues, it does not possess characters of the type from which ferns probably evolved, I must conclude that Archaeopteris is not a primitive, woody, arborescent fern.

I believe that Archaeopteris was not derived from any group which could reasonably be called a fern, although I realize the probability of the common ancestry of these groups, and the possibility that Archaeopteris might be of fern origin. Even if the group of which Archaeopteris was a member had been derived from a group of primitive ferns, the evidence suggests that its evolution was not in the direction of any other group of ferns, but rather, in the direction of the gymnosperms, and that it had evolved beyond the level at which it could reasonably be called a fern. The fern-like characters of this plant such as megaphyllous leaves, pteridophytic reproduction, foliar sporangia, and mesarch order of maturation of primary xylem do not conflict with this view. Megaphylly is common not only to ferns and progymnosperms, but also to pteridosperms and angiosperms. Pteridophytic reproduction characterizes all vascular plant groups except the gymnosperms and angiosperms, and the seed habit in these groups probably evolved from the pteridophytic condition by way of heterospory. Foliar sporangia occur in the lycopsids, the cycadophytes, the angiosperms, and, in the opinion of many, the coniferophytes, in addition to the ferns. Mesarch primary xylem is characteristic of, but not unique to, ferns, occurring also in primitive gymnosperms.

Evidence previously presented (Beck, 1960b) supports the second alternative listed above, that Archaeopteris was one of a large group of progymnosperms. Its arborescent, probably excurrent habit, megaphyllous leaves, secondary growth, circular bordered pits, ray tracheids, collateral vascular bundles, and probable heterosporous reproduction suggest that it was a type intermediate between the psilophyte and the seed plant: one advanced considerably beyond the primitive Lower and Middle Devonian psilophytic level and approaching that of the primitive Carboniferous gymnosperms.

ADDITIONAL SUPPORT FOR THE VIEW THAT 
ARCHAEOPTERIS IS A PROGYMNOSPERM-The view that Archaeopteris is a progymnosperm is further supported by the nature of its fertile foliage, since the morphology of its leaves suggests a type from which some pteridosperm fructifications might have evolved. In fact, Walton (1949a), in discussing Alcicornopteris hallei, a microsporangiate pteridosperm fructification, noted that "the structure of the branching axes indicated that they were parts of a frond and not stems"; and further, that "... [this fructification] seems relatively simple and may possibly be regarded as occupying an intermediate position between the type of organization found in the Upper Devonian Archaeopteris and the Upper Carboniferous synangial types."

Walton (1953a) proposed that the cupule of the Lagenostomales might have evolved by the fusion of sterile foliar segments around a cluster of ovules, a view supported by the morphology of the Calathospermum cupule, composed of 6 basally fused leaf-like segments, which surrounded a cluster of stalked seeds. Walton (1949b) writes: "The presence of a crescentric strand in the stalk of the cupule clearly suggests that the whole structure is morphologically equivalent to a frond or part of a frond." And further: "It is evident that in the evolution of the Calathospermum cupule, the telome system from which it was derived must have acquired the status of a dorsiventral lateral foliar organ not only in external features but in the structure of its vascular system before modification into an almost radially symmetrical cupule."

Support for Walton's view is presented in several recent papers. Eurystoma (Long, 1960) and Geminitheca (Smith, 1959), primitive lagenostomalean seeds from the Lower Carboniferous of Scotland, were borne on cupules considered to be derived from bilateral, dorsiventral leaves or branch systems. The "cupule" of Eurystoma was, in fact, little more than a somewhat curved, dorsiventral branch system.

Barnard (1960) has described a new species of Calathospermum, C. fimbriatum, and, on excellent evidence, like Walton, interprets the Calathospermum cupule as the equivalent of a large part of a dorsiventral frond. The main axis of the fructification described by Barnard has the morphology of a rachis. The basal part is slightly concave adaxially and contains vascular strands which form a shallow $U$ with the open end facing the adaxial surface. Proximal to the cupular segments, there are 2 opposite pairs of lateral pinnae in 1 plane. The main axis (rachis) is interpreted as branching, in the manner of many pteridosperm leaves. Primary pinnae, alternately arranged, arise from the branches of the main axis. The 2 proximal pinnae are fertile and bear seeds on branched secondary pinnae (pinnules), whereas the 3 distal are vegetative. The basic segments of the cupule are composed of the primary pinnae.
There are some close similarities between the fertile frond of Archaeopteris and the Calathospermum fructification. In Archaeopteris, as in $C$. fimbriatum, the most basal lateral appendages are frequently vegetative, most often taking the form of pinnules, but sometimes of pirnae (Johnson, $1911, \mathrm{pl}$. IV). These are followed by a series of fertile pinnae bearing predominantly fertile pinnules, but with the most proximal and dista] pinnules often being vegetative. The fertile pinnae are succeeded by a series of solely vegetative pinnae. In these features the Archaeopteris fertile leaf and Calathospermum are remarkably alike. If Barnard's interpretation is correct, and I see no reason for scepticism, the fertile leaf of $A r$ chaeopteris differs from Calathospermum in basic architecture only in its unbranched main rachis. It is not difficult to conceive of a fructification of the Calathospermum-Salpingostoma type having evolved through several intermediates from a fertile frond of a type similar to that of $A r$ chaeopteris. The strong evidence that some of the primitive pteridosperm seed-bearing fructifications were morphologically bilateral and dorsiventral foliar organs supports the view that Archaeopteris and similar gymnospermous pteridophytes might have been ancestral to some of the pteridosperms.

I have previously suggested that the cordaites as well as the pteridosperms might have evolved from the Progymnospermopsida. There is a conspicuous similarity in internal structure of both root and stem. In view of the foregoing discussion and of the clearly leaf-borne sporangia of Archaeopteris, however, those who adhere to the view that the cordaites are stachyosporous (i.e., with seeds borne terminally on axillary shoots or branches) will, no doubt, disagree. The concept of stachyospory as applied to the coniferophytes by Sahni (1920), and upheld by Lam and others, has never been acceptable to Florin, the foremost authority on the morphology and evolution of cordaite and primitive conifer fructifications. Schoute (1925), Florin (1939) and Eames (1952) agree that ovules as well as microsporangia of the cordaites are (in the words of Eames), "... borne terminally on an appendage, not terminally on an axillary shoot." One who studies Florin's massive and scholarly work on the evolution of the female coniferophyte cone, or who carefully reads his summary of this work (1951), can hardly fail to concur in this conclusion. The cordaitean fructification is, of course, very different from that of Archaeopleris. A single sporophyll of the axillary fertile shoot (strobilus) of Cordaites is, apparently, homologous with the entire fertile leaf of Archaeopteris. This difference, however, is not as basic as that between phyllospory and stachyospory, and the evolution of the primitive coniferophyte fructification from some progymnosperm remains a distinct possibility.

The evolution of the cordaite leaf from the 
pinnately compound type of the progymnosperm does, of course, present an organographic problem. But Delevoryas and Morgan (1954b), in discussing the possible relationship between Callistophyton and Poroxylon, have hypothesized that a simple cordaite-like leaf could be derived from a pinnate type by a suppression of the lateral leaf segments and a concurrent flattening and lateral expansion of the rachis.

Archaeopteris was, predominantly, an Upper Devonian genus, with several species extending into the Lower Mississippian whereas Cordaites seems to have existed primarily in the Pennsylvanian and later periods, possibly occurring earliest in the Upper Mississippian (see Walton, $1953 \mathrm{~b})$. The identification of a Lower Mississippian specimen as Cordaites, solely on the basis of secondary wood, by Cribbs (1935) is probably in error. These genera are, therefore, separated temporally by about 30 million years (see Kulp, 1961, for a new geologic time scale), during which time major evolutionary changes could have occurred. There is a large group of cordaite-like petrifaction genera including Endoxylon, Eristophyton, Bilignea, the "Cordaites" of Cribbs, Pycnoxylon, and others, all of Lower Mississippian age. Lacey (1953) has suggested that the first 3, often included with the Calamopityeae, should be grouped with the Cordaitales. Is it not possible that some of these genera represent intermediates between the progymnosperms of the Upper Devonian and the later Paleozoic cordaites and/or c n nifers?

There is an obvious similarity in leaf morphology between Archaeopteris and Lower Mississippian foliage genera such as Sphenopteridium, Adiantites, Rhodea, Rhacopteris, and Triphyllopteris (see Walton, 1931; Read, 1955). Some of these genera occur with fructifications, previously discussed, which are believed to belong to primitive pteridosperms, and with petrifaction genera such as Stenomyelon, Eristophyton, Protopitys, Bilignea and Calamopitys. Callixylon (the stem of Archaeopteris) occurs in great abundance in association with several of these same petrifaction genera in the New Albany shale, and shares many structural characteristics.

Archacopteris is closely similar in foliage and fructifications to the pteridosperms. It is similar in the anatomy of its primary body to both pteridosperms and some coniferophytes. In its secondary wood structure there is a remarkable resemblance to the coniferophytes.

Just where Archaeopteris fits in the scheme of progymnosperm and primitive gymnosperm evolution is impossible at present to conclude. That it is, indeed, a progymnosperm, not a fern precursor, is supported by much evidence. It seems to have been one of the more advanced genera among the progymnosperms and, as suggested by Arnold (1930) and Leclereq (personal communication, 1960), might have evolved concurrently with, and in some ways parallel to, both the primitive pteridosperms and coniferophytes. To determine finally whether this is a sound conclusion, as seems probable, or whether the genus was directly ancestral to some pteridosperms or coniferophytes, or some members of both groups, must await a more comprehensive knowledge of the plants represented by the numerous foliage and petrifaction genera of the Devonian and Mississippian.

\section{LITERATURE CITED}

Arnold, C. A. 1930. The genus Callixylon from the Upper Devonian of central and western New York. Papers Michigan Acad. 11: 1-50.

1931. On Callixylon newberryi (Dawson) Elkins et Wieland. Contr. Mus. Paleontol. Univ. Michigan $3: 207-232$.

- 1935. On seedlike structures associated with Archaeopteris, from the Upper Devonian of northern Pennsylvania. Contr. Mus. Paleontol. Univ. Michigan 4: $283-286$.

_. 1936. Observations on fossil plants from the Devonian of eastern North America. II. Archaeopteris macilenta and A. sphenophyllifolia of Lesquereux. Contr. Mus. Paleontol. Univ. Michigan 5: 49-56.

- 1939. Observations on fossil plants from the Devonian of eastern North America. IV. Plant remains from the Catskill Delta deposits of northern Pennsylvania and southern New York. Contr. Mus. Paleontol. Univ. Michigan 5: 271-313.

1947. An introduction to paleobotany. McGraw-Hill Book Co., Inc., New York.

Bailey, I. W. 1925. Some salient lines of specialization in tracheary pitting. I. Gymnospermae. Ann. Bot. 34: $586-598$.

- 1953. Evolution of the tracheary tissue of land plants. Amer. Jour. Bot. 40: 4-8.

BARNARd, P. D. 1960 . Calathospermum fimbriatum sp. nov., a Lower Carboniferous pteridosperm cupule from Scotland. Paleontology 3: 265-275.

BAxter, R. W. 1951. Ankyropteris glabra, a new American species of the Zygopteridaceae. Amer. Jour. Bot. 38: 440-452.

1952. The coal-age flora of Kansas. II. On the relationships among the genera Etapteris, Scleropteris, and Botrychioxylon. Amer. Jour. Bot. 39: 263-274.

Веск, C. B. 1953. A new root species of Callixylon. Amer. Jour. Bot. 40:226-233.

1960a. Connection between Archaeopteris and Callixylon. Science 131: 1524-1525.

- 2. 1960b. The identity of Archaeopteris and Callixylon. Brittonia 12: 351-368.

Bennett, R. E. 1959. Geology of East Bourland and Simpson Springs Mountains, Brewster County, Texas. Thesis. Univ. of Texas, Austin.

Bierhorst, D. W. 1960 . Observations on tracheary elements. Phytomorphology 10: 249-305.

BoLd, H. C. 1956. Some aspects of the classification of the plant kingdom. Bull. Assoc. Southeast. Biol. 3: $1-5$.

Bower, F. O. 1923, 1926, 1928. The ferns. Vols. I, II, III. Univ. Press, Cambridge.

Copeland, E. B. 1947. Genera filicum. Chronica Botanica, Co., Waltham, Mass.

Cribrs, J. E. 1935. Cordaites missouriense from the Lower Carboniferous of Missouri. Amer. Jour. Bot. 22: $427-438$. 
Cronquist, A. 1960. Introductory botany. Harper and Brothers, New York.

Delevoryas, T., and J. Morgan. 1952, Tubicaulis multiscalariformis: A new American coenopterid. Amer. Jour. Bot. 39: 160-166.

- - 1954a. A further investigation of the morphology of Anachoropteris clavata. Amer. Jour. Bot. 41: 192-198.

- 1954 b. A new pteridosperm from the Upper Pennsylvanian deposits of North America. Palaeontographica 96B: 12-23.

Eames, A. J. 1936. Morphology of vascular plants. McGraw-Hill Book Co., Inc., New York.

-. 1952. Relationships of the Ephedrales. Phytomorphology 2: 79-100.

Eggert, D. A. 1959a. Studies of Paleozoic ferns: Tubicaulis stewartii sp. nov. and evolutionary trends in the genus. Amer. Jour. Bot. 46: 594-602.

- 1959b. Studies of Paleozoic ferns. The morphology, anatomy, and taxonomy of Ankyropteris glabra. Amer. Jour. Bot. 46: 510-520.

___ 1961. The occurrence of microphylls and megaphylls in Pennsylvanian members of the Zygopteridaceae. (Abstr.) Amer. Jour. Bot. 48: 541.

Farmer, J. B., and T. G. Hill. 1902 . On the arrangement and structure of the vascular strands in Angiopteris evecta, and some other Marattiaceae. Ann. Bot. 16: $371-402$.

Florin, R. 1939. The morphology of the female fructifications in cordaites and conifers of Paleozoic age. Bot. Notiser 1939: 547-565.

. 1951. Evolution in cordaites and conifers. Acta Hor ti Bergiani 15: 285-388.

Frost, F. H. 1931. Specialization in secondary xylem of dicotyledons. III. Specialization of lateral wall of vessel segment. Bot. Gaz. 91: 88-96.

Holtwum, R. E. 1949. The classification of ferns. Biol. Rev. 24: 267-296.

Johnson, T. 1911. Is Archaeopteris a pteridosperm? Sci. Proc. Roy. Dublin Soc., N. S., 13: 114-136.

KräUsel, R., and H. Weyland. 1941. Pflanzenreste aus dem Devon von Nord-Amerika. II. Die Oberdevonischen Floren von Elkins, West-Virginien, und Perry, Maine, mit Berücksichtigung einiger Stücke von der Chaleur-Bai, Canada. Palaeontographica 86B: 3-78.

Kulp, J. L. 1961. Geologic time scale. Science 133: $1105-1114$.

Lacey, W. S. 1953. Scottish Lower Carboniferous plants: Eristophyton waltoni sp. nov. and Endoxylon zonatum (Kidston) Scott from Dunbartonshire. Ann. Bot., N. S., 17: 579-596.

Leclerco, S. 1951. Étude morphologique et anatomique d'une fougère du Dévonien supérieur, le Rhacophyton zygopteroides nov. sp., Ann. Soc. Géol. Belgique 9: 1-62.

— AND H. P. Banks. 1959. Pseudosporochnus is not a psilophyte. (Abstr.) Proc. IX Internat. Bot. Congr. Vol. II, p. 219-220.

Iesquereux, L. 1879, 1884. Description of the coal flora of the Carboniferous formation in Pennsylvania and throughout the United States. Second Geol.
Surv. Pennsylvania. Atlas; Vol. III. Rept. of Progress P. Harrisburg.

LoNG, A. G. 1960. On the structure of Samaropsis scotica Calder (emended) and Eurystoma angulare gen. et sp. nov., petrified seeds from the Calciferous Sandstone Series of Berwickshire. Trans. Roy. Soc. Edinburgh 64: 261-280.

Morgan, J., ANd T. Delevoryas. 1954. An anatomical study of a new coenopterid and its bearing on the morphology of certain coenopterid petioles. Amer. Jour. Bot. 41: 198-203.

Nathorst, A. G. 1902. Zur Oberdevonischen Flora der Bären-Insel. J. Svenska Vetenskaps-Akad. Handl. $36(3): 1-60$

Posthumus, O. 1924. Osmundites kidstoni, Stopes. Ann. Bot. 38: 215-216.

Read, C. B. 1955. Floras of the Pocono Formation and Price Sandstone in parts of Pennsylvania, Maryland, West Virginia, and Virginia. U. S. Geol. Surv. Prof. Paper 263: 1-32.

Sahni, B. 1920. On the structure and affinities of Acmopyle pancheri, Pilger. Phil. Trans. Roy. Soc. London B210: 253-310.

- 1932. On the structure of Zygopteris primaria (Cotta) and on the relations between the genera Zygopteris, Etapteris and Botrychioxylon. Phil. Trans. Roy. Soc. London B222: 29-46.

Schimper, W. P. 1869. Traité de Paléontologie Végétale. Vol. I and Atlas.

Schmalhausen, J. 1894. Über Devonische Pflanzen aus dem Donetz-Becken. Mem. Com. Geol. 8(3): 1-36.

Schoute, J. C. 1925. La nature morphologique de bourgeon féminin des Cordaites. Rec. Trav. Bot. Néerl. 12: 113-127.

ScotT, D. H. 1920, 1923. Studies in fossil botany. Vols. I + II. A. and C. Black, Ltd., London.

Smith, D. L. 1959. Geminitheca scotica gen. et sp. nov.; a pteridosperm from the Lower Carboniferous of Dunbartonshire. Ann. Bot., N. S., 23: 477-491.

Stopes, M. C. 1921. The missing link in Osmundites. Ann. Bot. 35: 55-61.

Walton, J. 1931. Contributions to the knowledge of Lower Carboniferous plants. III. On the fossil flora of the Black Limestones in Teilia Quarry, Gwanysgor, near Prestatyn, Flintshire, with special reference to Diplopteridium teilianum Kidston sp. (gen. nov.) and some other fern-like fronds. Phil. Trans. Roy. Soc. London B219: 347-379.

- 1949a. A petrified example of Alcicornopteris (A. hallei sp. nov.) from the Lower Carboniferous of Dunbartonshire. Ann. Bot., N. S., 13: 445-452.

- 1949b. Calathospermum scoticum-an ovuliferous fructification of Lower Carboniferous age from Dunbartonshire. Trans. Roy. Soc. Edinburgh 61: 719-728.

- 1953a. The evolution of the ovule in the pteridosperms. The Advancement of Science, No. 38: $1-7$.

- - 1953b. An introduction to the study of fossil plants, 2d. ed. A. and C. Black, London.

Wilson, L. R. 1958. Oklahoma's oldest fossil trees. Oklahoma Geol. Notes 18: 173-177. 